\title{
p38 MAPK and MSK1 mediate caspase-8 activation in manganese-induced mitochondria-dependent cell death
}

\author{
B El Mchichi ${ }^{1,2}$, A Hadji $^{1,2}$, A Vazquez $^{1}$ and G Leca ${ }^{\star, 1}$
}

\begin{abstract}
Heavy metals are important regulators of cell apoptosis. Manganese $\left(\mathrm{Mn}^{2+}\right)$ is a potent inducer of apoptosis in different cell types, but the precise mechanisms that mediate such effects are not well defined. We previously reported that $\mathrm{Mn}^{2+}$ was a potent apoptotic agent in human B cells, including lymphoma B cell lines. We show here that $\mathrm{Mn}^{2}{ }^{+}$-induced cell death in human $B$ cells is associated with caspase-8-dependent mitochondrial activation leading to caspase-3 activity and apoptosis. We used specific caspase-8 interfering shRNAs to reduce caspase-8 expression, and this also reduced $\mathrm{Mn}^{2+}$-induced caspase-3 activation and apoptosis. $\mathrm{Mn}^{2+}$-triggered caspase- 8 activation is associated with a specific pathway, which is independent of Fas-associated death domain protein, and dependent on the sequential activation of p38-mitogen-activated protein kinase (p38 MAPK) and mitogen- and stress-response kinase 1 (MSK1). Inhibition of p38 activity using either pharmacological inhibitors or dominant-negative mutant forms of p38 blocked $\mathrm{Mn}^{2+}$-mediated phosphorylation of MSK1 and blocked subsequent caspase-8 activation. However, specific inhibitors and the expression of a dominant-interfering mutant of MSK1 only inhibited caspase-8 activation, but not p38 activity. These findings suggest a novel model for the regulation of caspase- 8 during $\mathrm{Mn}^{2+}$-induced apoptosis based on the sequential activation of p38 MAPK, MSK1, caspase-8 and mitochondria, respectively.

Cell Death and Differentiation (2007) 14, 1826-1836; doi:10.1038/sj.cdd.4402187; published online 22 June 2007
\end{abstract}

Exposure to divalent heavy metals such as manganese $\left(\mathrm{Mn}^{2+}\right)$ has been linked to several neurological disorders, including Parkinson's-like syndrome. ${ }^{1}$ High concentrations of $\mathrm{Mn}^{2+}$ can provoke a series of intracellular molecular events that lead to apoptosis. ${ }^{2-5}$ The mechanism by which $\mathrm{Mn}^{2+}$ induces cell death is somewhat controversial and not well understood. Several lines of evidence suggest that treatment of cells by $\mathrm{Mn}^{2+}$ induces different cellular changes, depending on the cell types studied. In neuronal cells, $\mathrm{Mn}^{2+}$ can be transported into the cells via the transport protein divalent metal transporter 1, a mechanism similar to that used for iron. 6,7 This transport may generate increased oxidative stress with the subsequent induction of signal transduction pathways, leading to apoptosis. Reactive oxygen species (ROS) derived from mitochondrial damage have been implicated in cell-signaling pathways that lead to $\mathrm{Mn}^{2+}$ induced apoptosis. ${ }^{8}$ Recent data suggest that caspase-3dependent proteolytic activation of PKCO plays a role in $\mathrm{Mn}^{2+}$-induced apoptotic cell death. ${ }^{9,10}$ In HeLa and NIH3T3 cell lines, $\mathrm{Mn}^{2+}$ induces apoptosis via a caspase-12dependent pathway, independent of the mitochondria and involving the participation of $p-38$ mitogen-activated protein kinase $(\mathrm{MAPK}){ }^{3,11}$ This suggests that transduction pathways mobilized by $\mathrm{Mn}^{2+}$ may differ according to the targeted cell. The MAPK are key regulators of cell proliferation, differentiation, survival and apoptosis. There are three major groups of MAPKs: extracellular signal-regulated kinase (ERK), c-jun N-terminal kinase (JNK)/stress-activated protein kinase and p38 MAPK. The involvement of MAPK in the generation of stress responses, as well as in signaling for various cytokines and growth factors, has been extensively studied. $^{12-14}$ A variety of stress stimuli, including metals, engage the MAPK super family to participate in the apoptotic process. Among them, arsenic trioxide, which is a potent inducer of apoptosis, has been extensively studied. ${ }^{15}$ In leukemia cells treated with arsenic trioxide, the p38 MAPK activating cascade acts as a negative regulatory feedback for antileukemic effects. ${ }^{16}$ Downstream from the p38 MAPK activating pathway induced by arsenic, the stress-activated protein kinase 1 (MSK1) plays a role in this negative regulatory process. ${ }^{17}$ On the other hand, oxidative stress in neurons initiates p-38 MAPK activation that is linked to caspase-8 and -9-dependent apoptosis. ${ }^{18}$ We reported that p38 MAPK activation by transforming growth factor (TGF) $\beta$

${ }^{1}$ INSERM, UMR542, Université Paris-Sud, Hôpital Paul Brousse, Villejuif, France

*Corresponding author: G Leca, INSERM U542, Batiment Lavoisier, Hôpital Paul Brousse, 14 ave Paul Vaillant Couturier, 94807 Villejuif, France.

Tel: + 331495811 52; Fax: + 331455953 43; E-mail: leca@ vjf.inserm.fr

${ }^{2}$ These authors contributed equally to this work

Keywords: manganese; caspase-8; p38 MAPK; MSK1; apoptosis

Abbreviations: $\mathrm{Mn}^{2+}$, manganese; DMSO, dimethyl sulfoxide; MAPK, mitogen-activated protein kinase; ERK, extracellular signal-regulated kinase; JNK, c-jun Nterminal kinase; SPAK, stress-activated protein kinase; MSK1, mitogen-and stress-response kinase 1; DMT1, divalent metal transporter 1; $\triangle \Psi M$, mitochondrial transmembrane potential; FADD, Fas-associated death domain protein; Cyt $c$, cytochrome $c$; zVAD-fmk, Z-Val-Ala-DL-Asp-fluoromethylketone; AEVDfmk, Ala-Glu-ValAsp-fluoromethyl ketone; IETD-fmk, Ile-Glu-Thr-Asp-fluoromethyl ketone; DiOC6, 3,39-dihexylocarbocyanin iodide; TRAIL, TNF-related apoptosis-inducing ligand; shRNAs, short hairpin RNAs; ROS, reactive oxygen species

Received 11.12.06; revised 24.5.07; accepted 24.5.07; Edited by SJ Martin; published online 22.6.07 
induces an apoptotic pathway via Fas-associated death domain protein (FADD)-independent activation of caspase-8 in human Burkitt lymphoma B cells. ${ }^{19}$

We previously showed that $\mathrm{Mn}^{2+}$ induced apoptosis in human $\mathrm{B}$ cells. ${ }^{5}$ This cell death was caspase-3-dependent and was inhibited by overexpression of $\mathrm{Bcl}-2$ protein. ${ }^{5,20} \mathrm{We}$ also showed that zinc, another divalent cation, exerted the opposite effect in human B lymphoma cells. ${ }^{20}$ At low concentrations $(<50 \mu \mathrm{M})$, zinc inhibited the loss of mitochondrial membrane potential $(\Delta \Psi \mathrm{M})$ and the activation of both caspase- 9 and caspase- 3 associated with apoptosis induced by $\mathrm{Mn}^{2+}$. Apoptosis induced by cellular stress is often mediated through the mitochondria-triggered cell death pathway. ${ }^{21}$ As mitochondria participate in the apoptotic pathway induced by $\mathrm{Mn}^{2+}$, we sought to identify their role in this process. In this study, we analyzed the upstream effectors involved in the mitochondrial dysfunction pathway induced by $\mathrm{Mn}^{2+}$ in lymphoma B cells in more detail. We found that $\mathrm{Mn}^{2+}$ induced activation of caspase-8, which in turn regulated mitochondria aberrations associated with the release of cytochrome $c$ (Cyt $c$ ) via the Bid cleavage molecule, followed by caspase- 3 activation. The caspase- 8 activation was independent of FADD. The use of short hairpin RNA (shRNA) specific for caspase-8 blocked caspase-3 activation and apoptosis. We showed that p38 MAPK and MSK1 were activated in response to $\mathrm{Mn}^{2+}$ cell treatment, and they were critical for caspase-8 activation. Using specific pharmacological inhibitors and dominant-negative mutants of $p-38$ MAPK and MSK1, we found that p38 MAPK is the upstream effector that controls the activation of MSK1; this sequence of events leads to the $\mathrm{Mn}^{2+}$-dependent activation of caspase- 8 . Altogether, these data reveal a novel mechanism for regulating caspase-8 activity in human B cells based on the sequential activation of $\mathrm{p}-38$ MAPK and MSK1 leading to caspase- 8 and mitochondrial activation.

\section{Results}

Manganese-induced cell death occurs via the mitochondrial pathway and involves caspase- 8 activation in human $\mathbf{B}$ cells. We initially reported that $\mathrm{Mn}^{2+}$ apoptosis in lymphoma B cell was caspase-3-dependent. ${ }^{5}$ Other groups reported similar results using other cell types. ${ }^{3,22}$ Nevertheless, the pathway responsible for caspase-3 activation remains unclear. Oubrahim et $a l^{3}$ reported that $\mathrm{Mn}^{2+}$-dependent caspase-3 in HeLa and NIH3T3 cell lines was independent of mitochondrial activation. In contrast, Figure 1 shows that $\mathrm{Mn}^{2+}$ leads to mitochondrial modifications in human lymphoma B cells. Similar kinetic dose-effect curves were observed in the BL41 Burkitt lymphoma cell line treated with $\mathrm{Mn}^{2+}$, with regard to apoptosis quantified by cell shrinkage or mitochondrial alterations quantified by mitochondrial membrane potential loss $(\triangle \Psi M)$ measured either using 3,39-dihexylocarbocyanin iodide (DIOC6) or the MitoTracker Red CMXRos (data not shown) (Figure 1a). $\mathrm{Mn}^{2+}(400 \mu \mathrm{M})$ induced the release of mitochondrial Cyt $c$ into the cytosol with similar kinetics. Mitochondrial modifications, as measured by both criteria ( $\triangle \Psi \mathrm{M}$ and Cyt $c$ release), were observed after $8 \mathrm{~h}$ of activation by $400 \mu \mathrm{M} \mathrm{Mn}^{2+}$ with a maximum at $14 \mathrm{~h}$ (Figure $1 \mathrm{a}$ and $\mathrm{b}$ ).
Since caspase-8 is an important regulator of mitochondrial activation, we investigated its involvement during $\mathrm{Mn}^{2+}$ activation of BL41 cells. Figure 1c shows that caspases were responsible for mitochondrial activation since $\triangle \Psi \mathrm{M}$ loss was prevented by the pan-caspase inhibitor Z-Val-Ala-DL-Aspfluoromethylketone (zVAD-fmk) $(50 \mu \mathrm{M})$ and by the more specific caspase-8 inhibitor Ala-Glu-Val-Asp-fluoromethyl ketone (AEVD-fmk) $(50 \mu \mathrm{M})$, suggesting that $\Delta \Psi \mathrm{M}$ loss was dependent on caspase-8 activation. We further verified that $\mathrm{Mn}^{2+}$ could activate caspase-8 (Figure 1d). The presence of $\mathrm{Mn}^{2+}(400 \mu \mathrm{M})$ induced the expression of the $\mathrm{p} 43 / 45 \mathrm{kDa}$ and p18 cleaved active forms of caspase-8. Caspase- 8 activation in BL41 cells was observed as early as $7 \mathrm{~h}$ after adding $\mathrm{Mn}^{2+}$ $(43 / 45 \mathrm{kDa})$. The kinetics were confirmed by studying the cleavage of the natural caspase- 8 substrate, Bid. Cleavage of Bid was observed after $7 \mathrm{~h}$ of $\mathrm{Mn}^{2+}$ treatment and was nearly complete after $9 \mathrm{~h}$ (Figure 1d). Caspase-3 activation was more delayed than caspase- 8 activation, starting after $9 \mathrm{~h}$ and it was more pronounced after $11 \mathrm{~h}$.

These data showed that $\mathrm{Mn}^{2+}$ could activate caspase-8, as shown by Bid cleavage, and that $\mathrm{Mn}^{2+}$ treatment caused mitochondrial $\triangle \Psi M$ loss and Cyt $c$ release.

Caspase-8 is indispensable for $\mathrm{Mn}^{2+}$-triggered mitochondrial activation and caspase-3 activation. To characterize the precise relationship between caspase-8 and caspase-3, we determined whether or not inhibition of caspase- 8 in the presence of the specific inhibitors (Ile-GluThr-Asp-fluoromethyl ketone (IETD-fmk) and AEVD-fmk) could prevent caspase-3 activation. In Figure $2 \mathrm{a}, 50 \mu \mathrm{M}$ IETD and $50 \mu \mathrm{M}$ AEVD prevented both caspase-8 and caspase-3 activity, as measured by the fixation of their specific fluorogenic substrates. Similarly, Western blot analysis showed that the active cleaved forms of both caspase- 8 and caspase- 3 disappeared in the presence of the caspase-8 inhibitors IETD-fmk and AEVD-fmk (Figure 2b). Both zVAD-fmk and IETD-fmk or AEVD-fmk inhibited, to a similar extent, the $\mathrm{Mn}^{2+}$-induced cleavage of the natural caspase-3 substrate Mcl-1 (Figure 2b). These data showed that $\mathrm{Mn}^{2+}$-induced caspase-3 activation was dependent on caspase-8 activation.

Figure 1 showed that caspase- 8 could promote mitochondrial activation. We investigated whether caspase-8-dependent caspase-3 activation was mitochondria-dependent, using Ramos B lymphoma cell lines, one of which overexpressed Bcl-2. Normal Ramos cells were sensitive to $\mathrm{Mn}^{2+}$-induced apoptosis and $\triangle \Psi M$ decrease (Figure $3 a$ ). $\mathrm{Mn}^{2+}(400 \mu \mathrm{M})$ stimulation of these cells was associated with caspase- 8 and caspase-3 activation and Cyt $c$ release (Figure 3a). The kinetics of activation was faster than for BL41. Ectopic overexpression of Bcl-2 in Ramos B cells (Ramos/Bcl-2) rendered these cells resistant to $\mathrm{Mn}^{2+}$ mediated apoptosis ${ }^{5}$ (Figure $3 b$ ). Mitochondrial activation, as measured by $\triangle \Psi M$ loss and Cyt $c$ release, was inhibited in Ramos/Bcl-2 cells, and this inhibition was also associated with an inhibition of $\mathrm{Mn}^{2+}$-induced caspase- 3 activation. These data showed that $\mathrm{Mn}^{2+}$-induced caspase- 3 activation was dependent on the mitochondria. In contrast, activation of caspase- 8 by $\mathrm{Mn}^{2+}$ was still observed in these cells. Altogether, these data are compatible with the hypothesis 

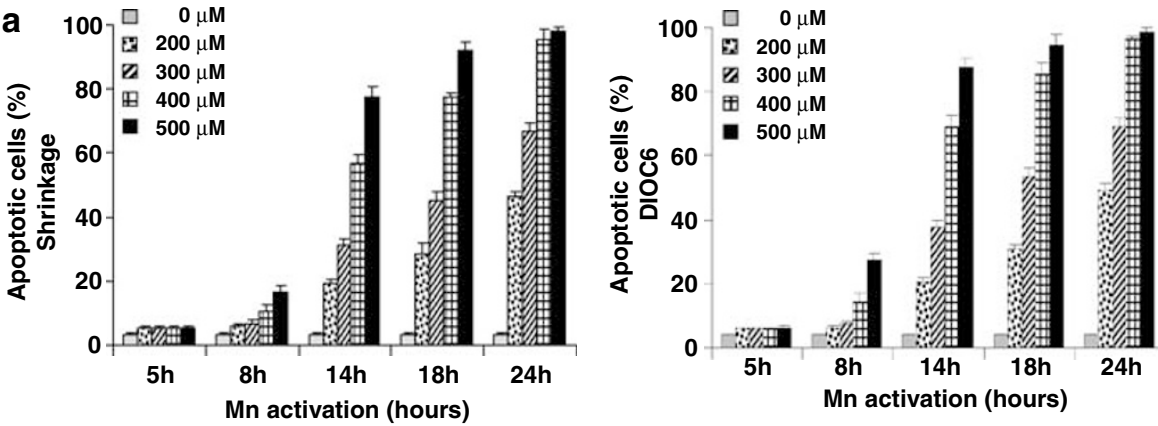

b

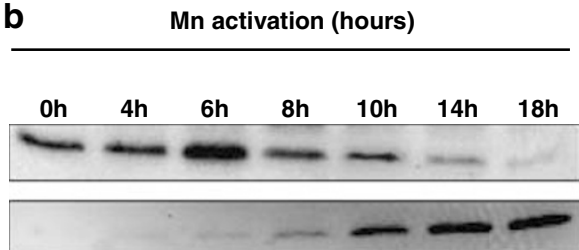

Cytochrome C
Heavy membrane

Cytosol
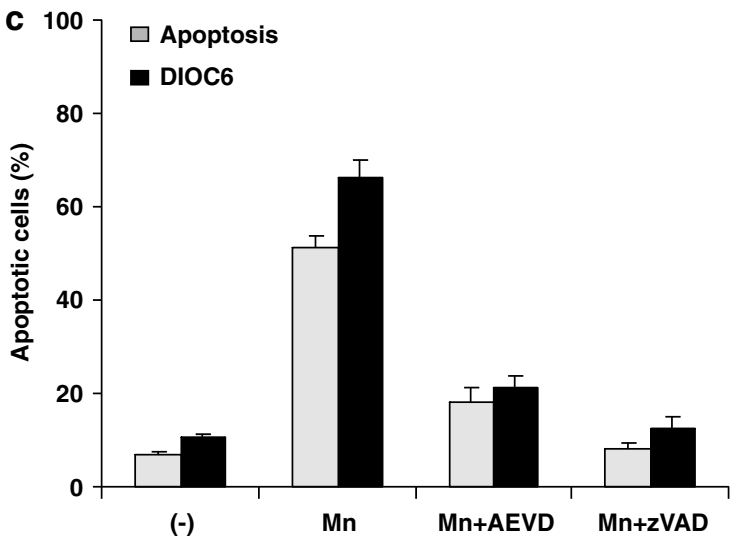

d

Mn activation (hours)
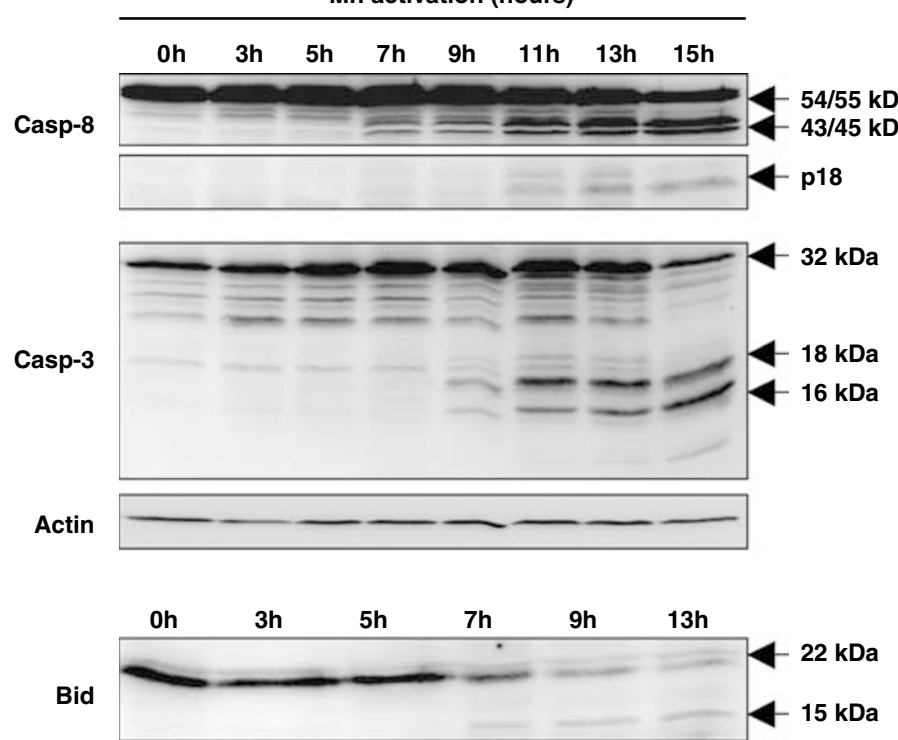

Figure $1 \mathrm{Mn}^{2+}$ induces the caspase-8-dependent loss of $\Delta \Psi \mathrm{M}$ and apoptosis. (a) BL41 cells cultured with various concentrations of $\mathrm{Mn}^{2+}$ for various periods of time. Cells were assessed by flow cytometry and were considered apoptotic when they were shrunken, with high side scatter and low forward scatter properties. Apoptotic cells were counted and expressed as a percentage of the total number of cells. After DIOC6 staining, $\Delta \Psi M$ was assessed by flow cytometry. Cells with low $\Delta \Psi M$ were counted and expressed as a percentage of the total population. Data represent the mean +S.D. of three determinations. (b) Cytosolic and heavy membrane (enriched in mitochondria) extracts were prepared from BL41 cells that had been cultured with $\mathrm{Mn}^{2+}(400 \mu \mathrm{M})$ for various periods of time. Immunoblots were probed with anti-cytochrome $c$ Ab. (c) BL41 cells were cultured for $13 \mathrm{~h}$ without $(-)$, with $400 \mu \mathrm{M} \mathrm{Mn}^{2+}(\mathrm{Mn})$, and in combination with $50 \mu \mathrm{M}$ of the pan-caspase inhibitor zVAD-fmk (Mn $+\mathrm{zVAD}$ ) or with $50 \mu \mathrm{M}$ of the caspase-8 specific inhibitor AEVD-fmk (Mn + AEVD). Cell shrinkage and the loss $\triangle \Psi M$ (DIOC6) were assessed by flow cytometry, as described in panel A. Data represent the mean \pm S.D. of three determinations. (d) Cells were cultured with $\mathrm{Mn}^{2+}(400 \mu \mathrm{M})$ for various periods of time. Whole cell extracts were separated by SDS-PAGE, and immunoblots were probed with specific anti-caspase-8, anti-caspase-3, anti-bid and anti-actin antibodies

that caspase- 3 activation in $\mathrm{Mn}^{2+}$-treated human lymphoma $\mathrm{B}$ cells is directly controlled by caspase-8-mediated mitochondrial activation.
To establish the relevance of caspase- 8 in the regulation of $\mathrm{Mn}^{2+}$-induced apoptosis, we used specific shRNAs to reduce caspase-8 expression in a BJAB Burkitt lymphoma cell line. 
a
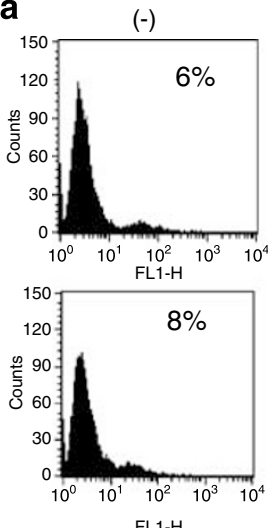

$\mathrm{FL} 1-\mathrm{H}$

b

\section{Mn $400 \mu \mathrm{M}$ \\ zVAD $50 \mu \mathrm{M}$ \\ iETD $50 \mu \mathrm{M}$}

AEVD $50 \mu \mathrm{M}$
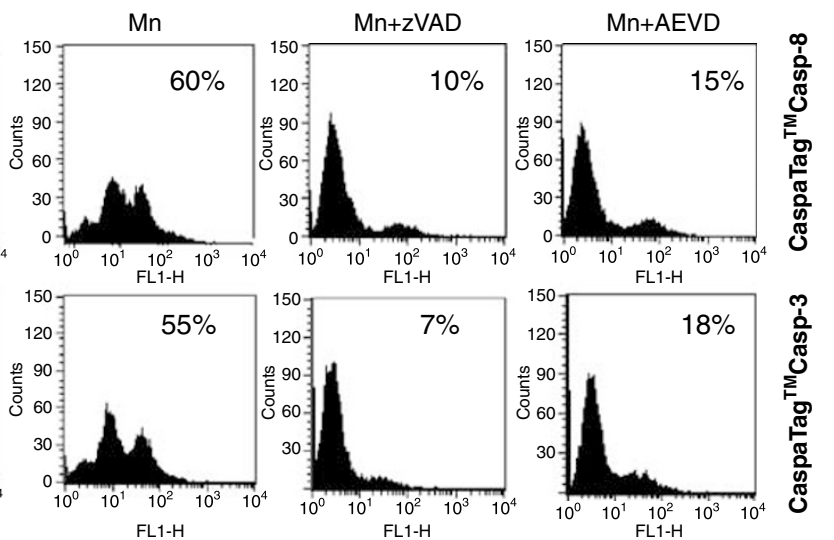

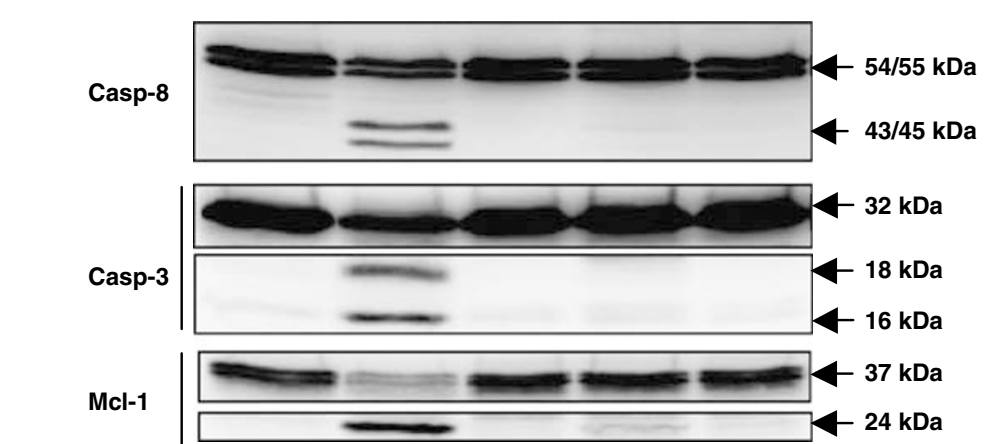

Figure $2 \mathrm{Mn}^{2+}$-mediated caspase- 8 activation controls caspase-3 activation and activity. (a) Representative data from flow cytometric analyses of BL41 cells after $13 \mathrm{~h}$ incubation without $(-)$, or with $400 \mu \mathrm{M} \mathrm{Mn}{ }^{2+}(\mathrm{Mn})$ alone, or in combination with $50 \mu \mathrm{M}$ zVAD-fmk (Mn + zVAD), or $50 \mu \mathrm{M}$ AEVD-fmk (Mn + AEVD). The frequency histograms of number of events ( $y$-axis) versus fluorescence intensity ( $x$-axis) show two peaks appearing at different fluorescence intensities. Caspase- 8 and caspase- 3 negative $(-)$ cells occur within the first log decade of the $x$-axis (FL1), whereas caspase-8- and caspase-3-positive $(+)$ cells are within the second and third log decade. (b) BL41 cells were cultured for $13 \mathrm{~h}$ without $(-)$, with $400 \mu \mathrm{M} \mathrm{Mn}^{2+}(\mathrm{Mn})$ in association with zVAD-fmk $(50 \mu \mathrm{M}), 50 \mu \mathrm{M}$ IETD-fmk or with $50 \mu \mathrm{M}$ AEVD-fmk. Lysates were immunoblotted for caspase-8, caspase-3 or Mcl-1 expression

This cell line, which is also sensitive to $\mathrm{Mn}^{2+}$-induced apoptosis, could be transfected to a higher level than the BL41 or Ramos cell lines. In the presence of the scrambled shRNA, $\mathrm{Mn}^{2+}$ promoted $\triangle \Psi M$ loss, apoptosis and caspase-8 and caspase-3 activation (Figure 4). Transfection of cells with the caspase- 8 shRNA ${ }^{23}$ resulted in a knockdown of the caspase-8 $54 / 55 \mathrm{kDa}$ pro-form expression. As illustrated in Figure 4, knockdown of caspase- 8 in the presence of $\mathrm{Mn}^{2+}$ was followed by a significant decrease in caspase- 8 and caspase- 3 activation, and was associated with an inhibition of apoptosis. These data strengthened our hypothesis that $\mathrm{Mn}^{2+}$ activates caspase-8, which in turn sequentially activates mitochondria and caspase-3.

Manganese-mediated caspase-8 activation is FADDindependent and requires activation of p38 MAPK. We next investigated the pathway responsible for $\mathrm{Mn}^{2+}$-induced caspase- 8 activation. First, we verified the involvement of the FADD molecule, the classical death domain adapter molecule for caspase-8 recruitment. We used FADD- dominant-negative BL41 clones that we previously described and which did not respond to tumor necrosis factor (TNF)related apoptosis-inducing ligand (TRAIL)-mediated apoptosis $^{24}$ (Figure 5a). $\mathrm{Mn}^{2+}$ promoted caspase-8 activation in these clones and this activation was associated with a $\Delta \Psi \mathrm{M}$ decrease and apoptosis, with similar kinetics to what had been observed in BL41 cells (Figure 1d and Figure $5 b$ ). Therefore, activation of caspase- 8 by $\mathrm{Mn}^{2+}$ is probably independent of the FADD adapter pathway.

To characterize the transduction pathway responsible for $\mathrm{Mn}^{2+}$-induced caspase-8 activation, we used different pharmacological inhibitors specific for various kinases, which play important roles in early transduction pathways. Among the different inhibitors tested (Figure 6), we observed a significant decrease in the expression of active cleaved forms of caspase- 8 in the presence of the p38 MAPK selective inhibitor SB203580. We also observed a significant decrease in caspase-8 cleavage in the presence of $\mathrm{H} 89$, a broad specificity kinase inhibitor that can inhibit the p38 target MSK1, among several other Ser/Thr kinases. ${ }^{25}$ Inhibitors of 
a

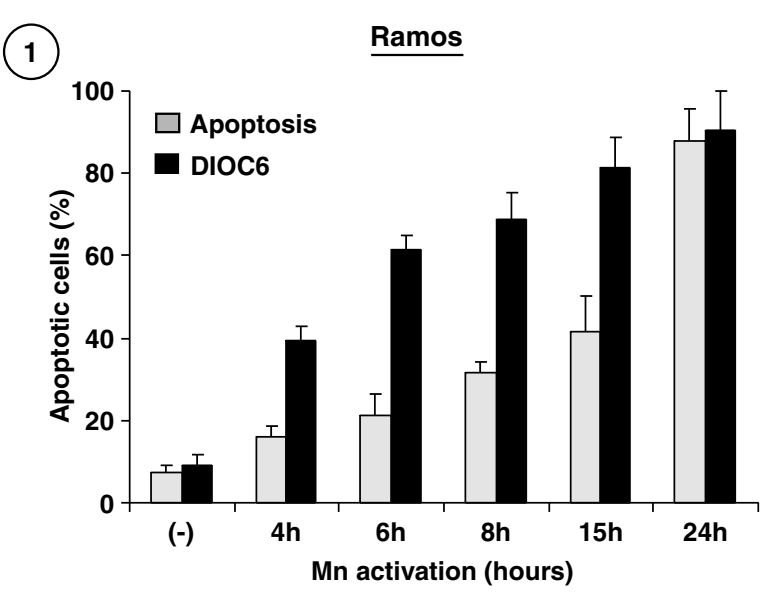

(2)

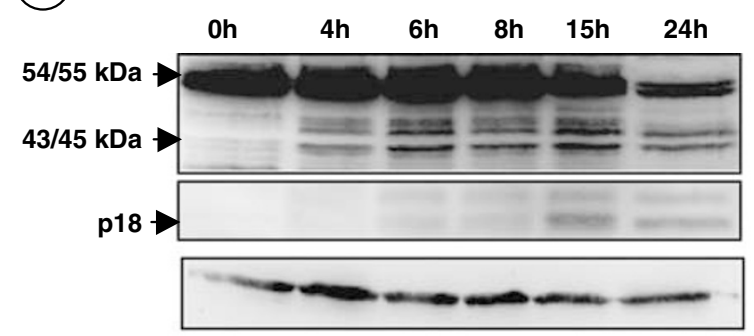

(3)

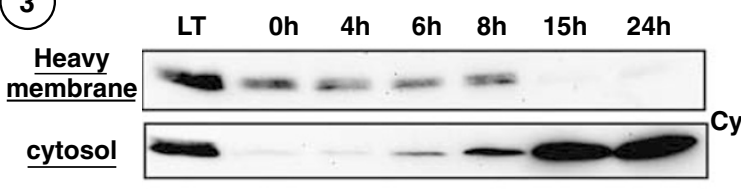

(4)

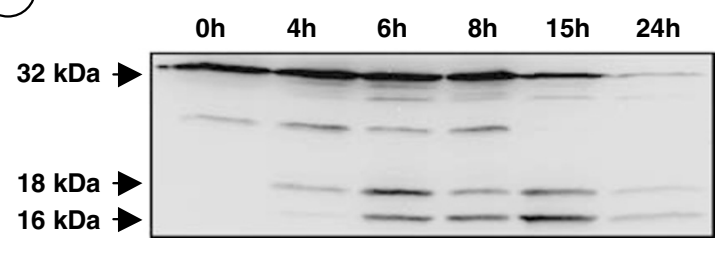

b

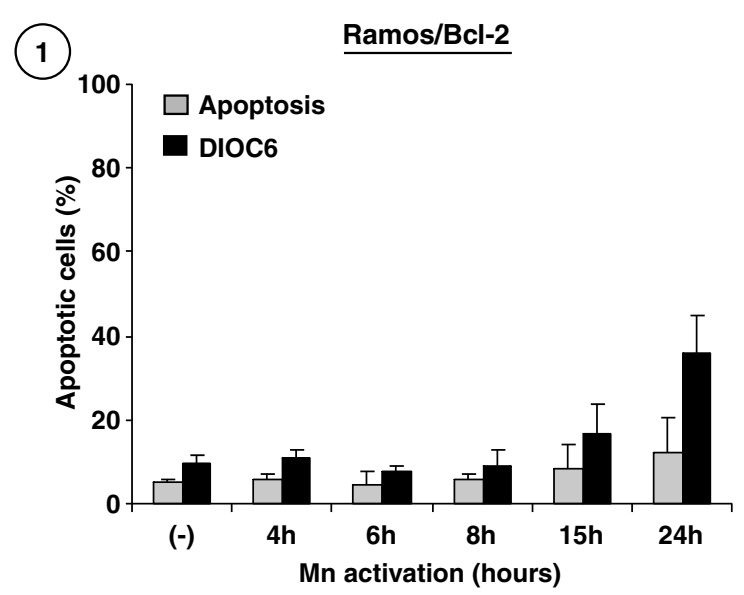

(2)

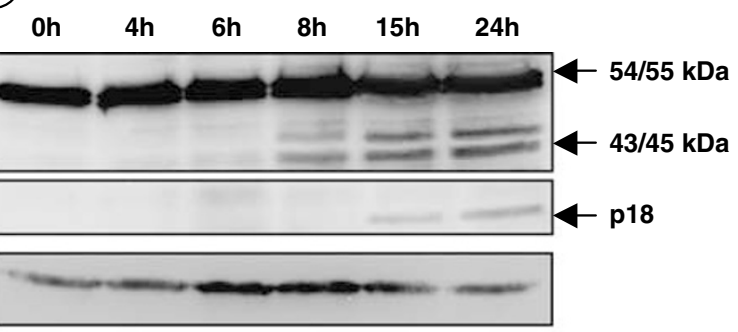

(3)

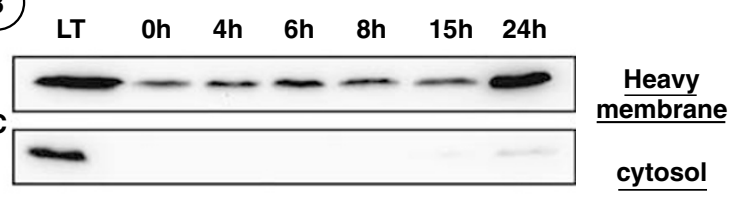

(4)

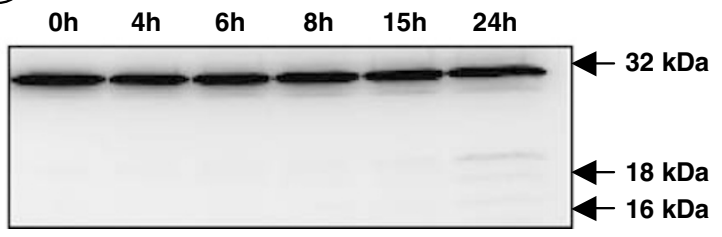

Figure $3 \mathrm{Mn}^{2+}$-mediated caspase-8 activation is upstream of mitochondrial modifications. Ramos (a) and Ramos-Bcl-2 (b) cells were cultured without (-) or with $400 \mu \mathrm{M}$ $\mathrm{Mn}^{2+}$ for various periods of time. Cell shrinkage and the loss of $\triangle \Psi M(\mathrm{DIOC6})$ were assessed by flow cytometry (a1, b1), as described in Figure 1. Data represent the mean \pm S.D. of three determinations. Whole cell extracts were subjected to SDS-PAGE, and the cleaved fragments of caspase-8 and caspase-3 were detected by immunoblotting with anti-caspase-8 Ab (a2, b2), anti-caspase-3 Ab (a4, b4) and anti-actin Ab (a2, b2). Cytosolic and heavy membrane (enriched in mitochondria) extracts were prepared from Ramos (a3) and Ramos-bcl-2 (b3) cells cultured without (-) or with $400 \mu \mathrm{M} \mathrm{Mn}^{2+}$ for various periods of time. Immunoblots were probed with anticytochrome $c A b$

other MAP-kinases, such as ERK (U0126 and PD98059) or JNK (SP600125), had little effect. Similarly, no modification of the PI3kinase pathway was observed in the presence of its specific inhibitors LY294002 and Wortmannin. Caspase-8 activation was inhibited by the pan-caspase inhibitor ZVADfmk, and by the more specific caspase-8 inhibitor AEVD. Other proteases, such as calpain, which may be responsible for $\mathrm{Mn}^{2+}$-mediated apoptosis in other cell types, ${ }^{11}$ were probably not involved in our system since the specific calpain inhibitor ALLM $(40 \mu \mathrm{M})$ did not prevent caspase-8 and caspase-3 activation, or apoptosis triggered by $\mathrm{Mn}^{2+}$ in BL41 cells. This pattern of reactivity was also observed with all the caspase-8 downstream events studied, which included cleavage of the caspase- 8 substrate Bid, $\Delta \Psi M$ decrease, caspase-3 activation and apoptosis (Figure 6a). We checked the ability of all these inhibitors to prevent in vitro caspase-8 activation using the synthetic substrate caspatag-8 (Figure 6b). Again, SB203580 and H89 significantly inhibited caspase-8 activity, confirming a role for p38 and MSK1 in $\mathrm{Mn}^{2+}$-mediated caspase-8 activation. 


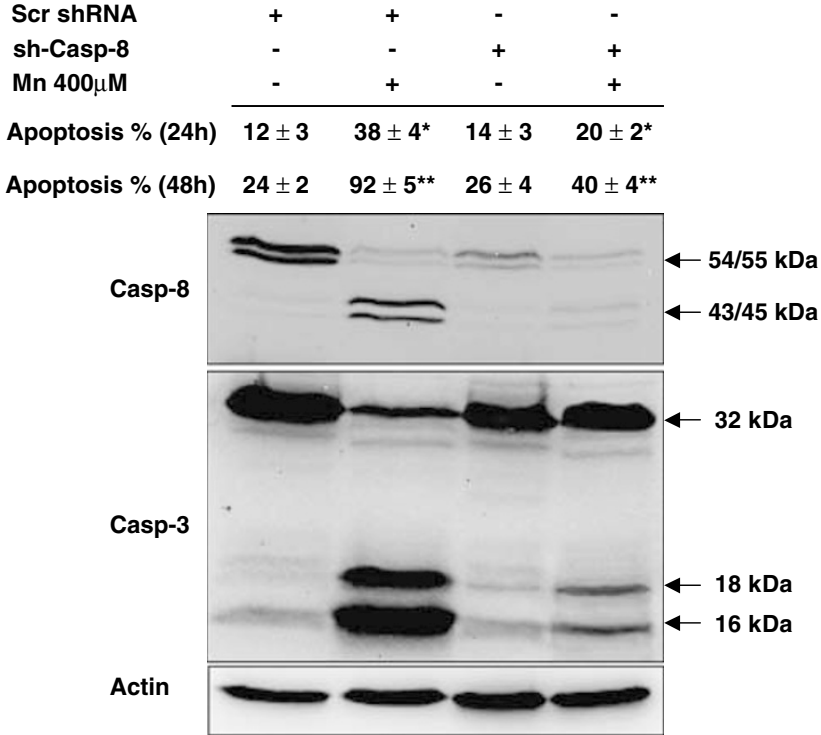

Figure 4 Knock-down expression of caspase-8 by RNA interference inhibits $\mathrm{Mn}^{2+}$-mediated caspase-3 activation and apoptosis. BJAB cells were transfected by electroporation with pLL3.7 vectors expressing shRNAs caspase-8-GFP (shcasp8), or scrambled shRNA-GFP (scr shRNA), plated and incubated for $48 \mathrm{~h}$ after GFP protein expression. GFP-positive cells were purified by flow cytometry, replated and immediately incubated with $\mathrm{Mn}^{2+}(400 \mu \mathrm{M})$ for $24 \mathrm{~h}$. Cell shrinkage was assessed by flow cytometry, as described in Figure 1. Lysates were immunoblotted with caspase-3, caspase-8 or actin Abs. The means + S.D. of three different measurements are shown. Results from one experiment out of three performed are shown. The differences between Mn-treated scr shRNA and Mntreated sh-casp-8 are statistically significant by $t$-test $\left({ }^{\star} P<0.05,{ }^{\star \star} P<0.001\right)$

Manganese-induced phosphorylation and activation of MSK1 are dependent on p38 MAPK activity. We next studied the ability of $\mathrm{Mn}^{2+}$ to trigger activation of $\mathrm{p3} 8$ and MSK1. As illustrated in Figure 7a, active phospho-p38 was detected by Western blot as early as $30 \mathrm{~min}$ after stimulation by $400 \mu \mathrm{M} \mathrm{Mn}^{2+}$, and it reached a plateau of activation after $6 \mathrm{~h}$. $\mathrm{Mn}^{2+}$ also induced phosphorylation of MSK1, but with delayed kinetics when compared to p38 (phospho-MSK1 appeared only after $3-4 \mathrm{~h}$ of stimulation and reached a plateau after $6 \mathrm{~h}$ of incubation). These data showed that (1) $\mathrm{Mn}^{2+}$ activated p38 and MSK1 in BL41 cells and (2) p38 was phosphorylated more rapidly than MSK1. This suggested that p38 may be responsible for the activation of MSK1 in $\mathrm{Mn}^{2+}$-treated BL41 cells, which would support our previous report using different experimental conditions. ${ }^{26}$ We studied the phosphorylation of p38 and MSK1 in the presence of various specific inhibitors to confirm the involvement of p38 in MSK1 activation by $\mathrm{Mn}^{2+}$ (Figure 7b). MSK1 phosphorylation was only prevented in the presence of the p38-selective inhibitor SB203580; as control H89 did not inhibit p38 phosphorylation, although the concentration used $(5 \mu \mathrm{M})$ prevented $\mathrm{Mn}^{2+}$-induced apoptosis. These data strongly suggested that under our experimental conditions, activation of MSK1 was dependent on p38 activation. These data also showed that p38 and MSK1 activation was caspase-independent since neither the pan caspase inhibitor (zVAD-fmk) nor the more specific caspase-8 (IETD) or caspase-3 (DEVD) inhibitors inhibited the sequential p38/MSK1 activation.
Overexpression of p38 MAPK and MSK1 dominantnegative mutants regulate caspase- 8 activation by $\mathbf{M n}^{2+}$. The preceding results showed that p38 activation was required for $\mathrm{Mn}^{2+}$-induced caspase- 8 activation and raised the possibility that MSK1, an H89-sensitive kinase and known p38 target, might also be involved. Consequently, experiments were designed to test this. The pattern of reactivity in BJAB cells in response to $\mathrm{Mn}^{2+}$ was similar to that previously observed in BL41 and Ramos cells, but with more delayed kinetics (Figure 8a). All of the following experiments were performed after $24 \mathrm{~h}$ of activation with $400 \mu \mathrm{M} \mathrm{Mn}^{2+}$ (Figure 8b). Overexpression of a dominantnegative form of p38 (p38AF) strongly prevented the expression of phospho-p38, phospho-MSK1 and active caspase- 8 promoted by $\mathrm{Mn}^{2+}$. Similarly, MSK1 and caspase- 8 activation were prevented by the specific p38 inhibitor SB203580. In contrast, $\mathrm{Mn}^{2+}$ activated MSK1 and caspase-8 in BJAB cells transfected with the pcMV5 plasmid control or with wild-type p38. Overexpression of the dominant-negative MSK1 form, which is mutated in the active kinase site (MSK1 CKD), did not prevent $\mathrm{Mn}^{2+}$. mediated p38 phosphorylation, but inhibited the appearance of active caspase-8 (Figure $8 \mathrm{c}$ ). Levels of caspase-8 activation induced by $\mathrm{Mn}^{2+}$ were similar in pCMV5 control transfected cells and in BJAB cells transfected with wild-type MSK1 plasmid. The pivotal roles of p38 MAPK and MSK1 for caspase-8 activation were highlighted by the observation that simultaneous overexpression of both active p38 and MSK1 seemed to be sufficient to promote caspase- 8 activation. Altogether, our data strongly suggested that $\mathrm{Mn}^{2+}$-triggered apoptosis is dependent on the sequential activation of p38, MSK1, caspase-8 and caspase-3.

\section{Discussion}

We previously reported that $\mathrm{Mn}^{2+}$ promoted apoptosis of human B cells via a caspase-3-dependent pathway, ${ }^{5}$ an observation that was confirmed by another group using other cell types, including HeLa and NIH3T3 cells. ${ }^{3,11}$ This group reported that caspase- 3 activation was independent of the mitochondrial pathway ${ }^{3}$ and dependent on caspase-12 activation. ${ }^{11}$ Since the active form of caspase- 12 was very limited in certain human ethnic groups, and since we had observed that $\mathrm{Mn}^{2+}$ could trigger apoptosis in all human $\mathrm{B}$ cell types from many different individuals, we decided to investigate $\mathrm{Mn}^{2+}$-mobilized pathways upstream of caspase-3 activation in human $B$ cells. Caspase- 3 can be activated via mitochondrial-dependent or -independent pathways. In contrast to recent evidence suggesting no role for mitochondria in $\mathrm{Mn}^{2+}$-induced apoptosis, ${ }^{3}$ our data clearly show that (1) $\mathrm{Mn}^{2+}$ induces $\triangle \Psi M$ loss and mitochondrial Cyt $c$ release, (2) overexpression of $\mathrm{Bcl}-2$ prevents Cyt $c$ release and caspase-3 activation and (3) $\mathrm{Mn}^{2+}$-induced mitochondrial alterations control caspase-3 activation ${ }^{5}$ (Figure 3 ). These effects were observed with concentrations of $\mathrm{Mn}^{2+}$ as low as $200 \mu \mathrm{M}$, although the maximum effect was observed with $400 \mu \mathrm{M}$. B cells were more sensitive to $\mathrm{Mn}^{2+}$ than HeLa or NIH3T3 cells, since experiments using these cells ${ }^{3,11}$ used a concentration of $1 \mathrm{mM} \mathrm{Mn}^{2+}$ to promote cell death, whereas a single dose of $200 \mu \mathrm{M} \mathrm{Mn}^{2+}$ was sufficient to promote apoptosis and 


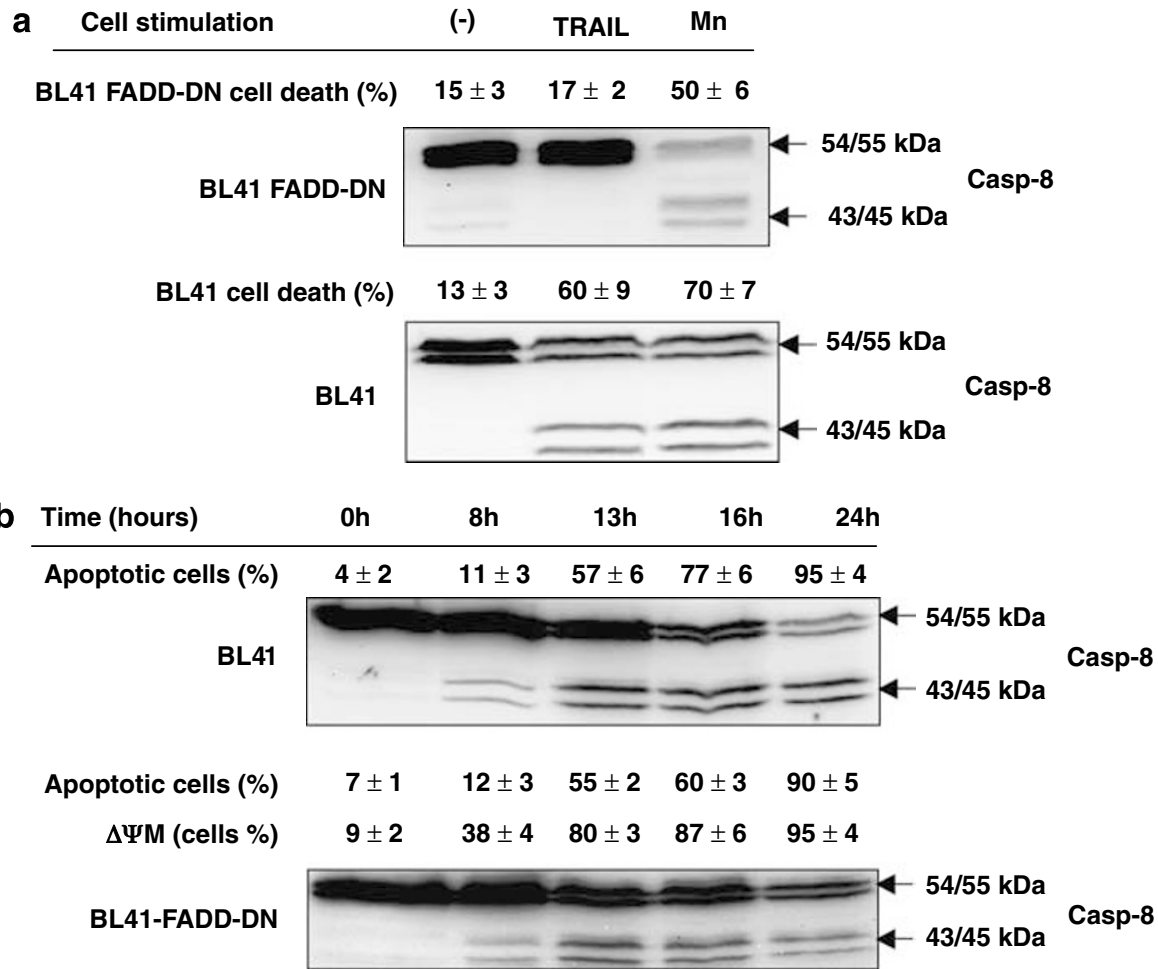

Figure $5 \mathrm{Mn}^{2+}$-mediated caspase-8 activation is FADD-independent. (a) BL41 cells producing endogenous FADD only, or BL41 cells expressing a truncated from of FADD (BL41-FADD-DN) were cultured for $13 \mathrm{~h}$ without (-), with $400 \mu \mathrm{M} \mathrm{Mn}^{2+}$, or with recombinant human TRAIL (200 ng/ml). Shrunken apoptotic cells were counted by flow cytometry, as described in Figure 1, and caspase-8 cleavage was assessed by Western blotting with anti-caspase-8 Ab. (b) BL41 or BL41-FADD-DN cells were stimulated without (-), or with $400 \mu \mathrm{M} \mathrm{Mn}^{2+}$ for various periods of time. Cell shrinkage and $\Delta \Psi \mathrm{M}$ loss (DIOC6) were assessed by flow cytometry, as described in Figure 1. Whole cell extracts were subjected to SDS-PAGE, and the cleavage of caspase-8 was determined with anti caspase-8 Abs. The data represent the means \pm S.D. of three individual measurements. Results from one experiment out of three performed are shown

mitochondrial activation of human B cells. Human B cell lines treated with a concentration of $1 \mathrm{mM} \mathrm{Mn}^{2+}$ developed characteristic features of necrotic cell death, suggesting that the pathway mobilized by $\mathrm{Mn}^{2+}$ might be dependent on the concentration used.

In our experimental model, mitochondrial activation was sensitive to the pan caspase inhibitor zVAD-fmk, clearly demonstrating the involvement of caspase- 8 in this process. $\mathrm{Mn}^{2+}$ activated caspase- 8 , as demonstrated by the appearance of the active cleaved forms, cleavage of the natural substrate Bid, or fixation of the specific synthetic substrate Caspatag-8. The role of caspase-8 in mitochondrial activation and in caspase- 3 activation was supported by the ability of specific caspase-8 inhibitors (IETD and AEVD) to prevent activation. Caspase- 8 can activate caspase- 3 through different pathways, either directly (type I) or through mitochondria (type II). ${ }^{27,28} \mathrm{Mn}^{2+}$-induced caspase-3 activation was more similar to the type II pathway, since $\mathrm{Bcl}-2$ overexpression, which inhibits Cyt $c$ release and completely abrogates caspase- 3 activation, did not prevent caspase- 8 activation. Thus, in lymphoma $\mathrm{B}$ cells, $\mathrm{Mn}^{2+}$-induced caspase- 3 activation is dependent on caspase-8-mediated mitochondrial activation.

The major pathway of caspase- 8 activation is based on death receptor-dependent recruitment of the FADD adapter molecule, which in turn promotes dimerization and subsequent activation of this caspase. ${ }^{29} \mathrm{Mn}^{2+}$-mediated caspase-8 activation was independent of the classical FADD pathway in our model since overexpression of a dominant-negative form of FADD lacking the DED domain that abolished the TRAIL response $^{24}$ (Figure 5) did not prevent caspase-8 activation and apoptosis triggered by $\mathrm{Mn}^{2+}$. Similar FADD-independent caspase-8 activation has already been described in other models using other apoptotic stimuli. ${ }^{19,24,30}$ We could not exclude that interaction between the non-DED domain of FADD with caspase- 8 might be involved in $\mathrm{Mn}^{2+}$-mediated caspase-8 activation as it has been reported in another system. ${ }^{31}$ However, we have not observed such an association using our experimental conditions (data not shown). We previously reported that $\mathrm{p} 38 \mathrm{MAPK}$ was involved in the control of caspase-8 activation by $\operatorname{TGF} \beta,{ }^{19}$ and we observed that $\mathrm{Mn}^{2+}$ triggered p38 activation in lymphoma B cells, as has been observed in other cell types. ${ }^{4,11,22,32}$ Here, we show that p38 is responsible for $\mathrm{Mn}^{2+}$-directed caspase- 8 activation in human $B$ cells.

The exact pathway responsible for p38-MAPK activation under our experimental conditions is not yet defined. The generation of ROS can trigger p38-MAPK activation. ${ }^{18,33}$ Since ROS generation is often associated with metal exposure, excessive ROS production is an important pathway by which metals can induce apoptosis. ${ }^{34}$ In a lethal concentration range, $\mathrm{Mn}^{2+}$ induced the production of $\mathrm{ROS}$, which is known to cause mitochondria-mediated apoptosis. ${ }^{35}$ However, in HeLa cells, $\mathrm{Mn}^{2+}$-induced apoptosis was not 
a

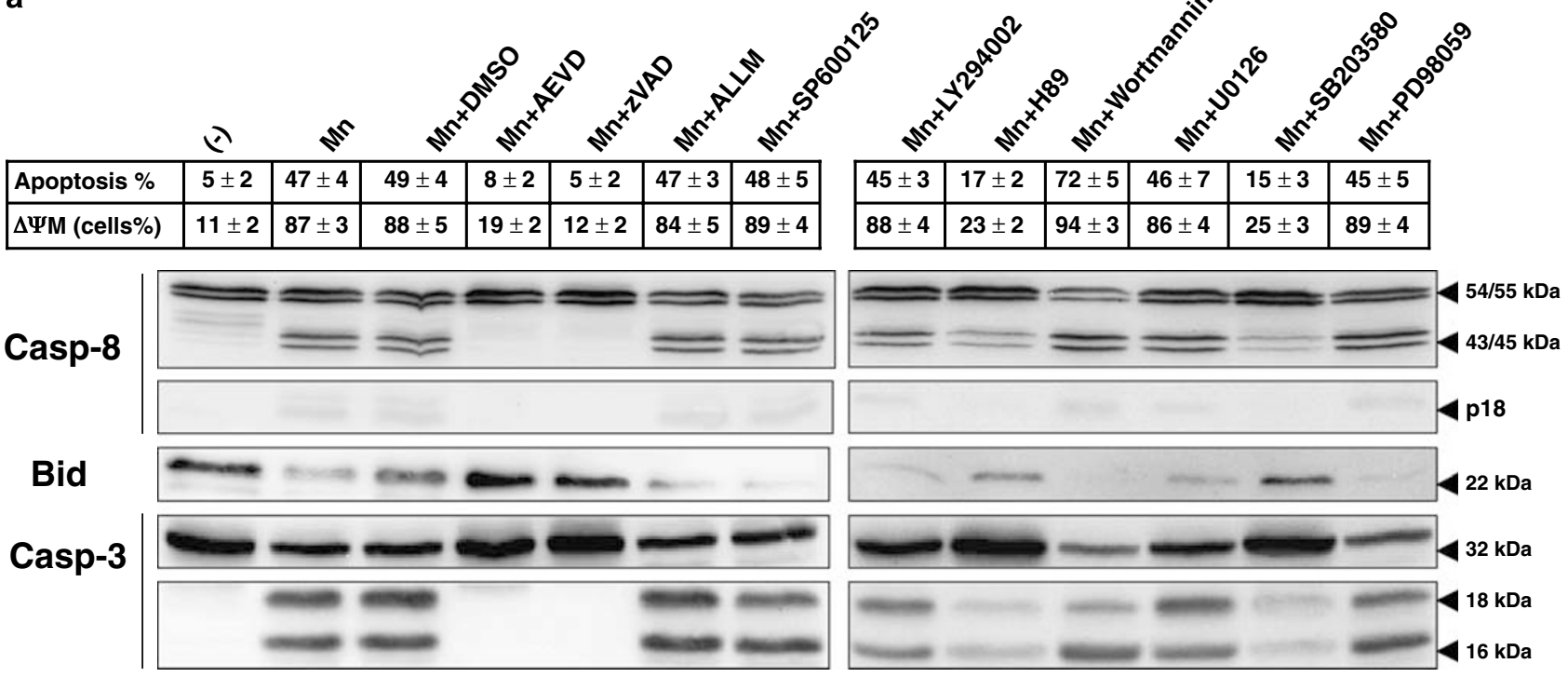

b

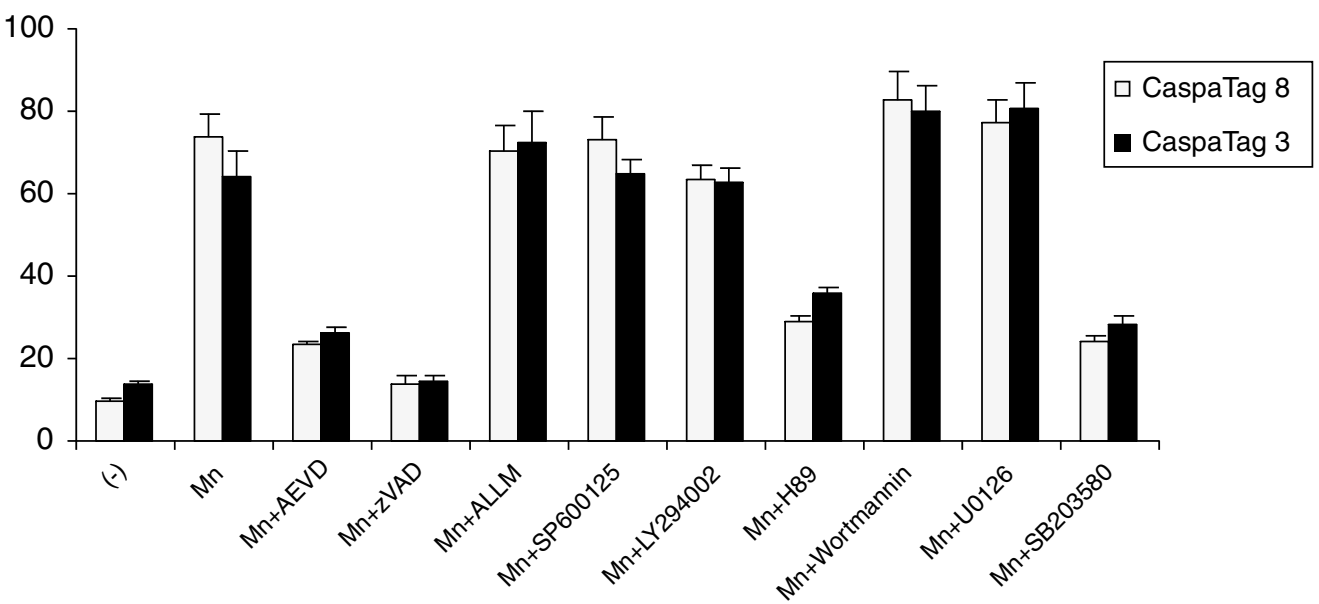

Figure $6 \mathrm{Mn}^{2+}$-mediated apoptosis and caspase-8 activation are dependent on P38-MAPK and MSK1. (a) BL41 cells were cultured for $13 \mathrm{~h}$ without (-), or with $400 \mu \mathrm{M}$ $\mathrm{Mn}^{2+}$ in the absence or presence of DMSO, AEVD-fmk $(50 \mu \mathrm{M})$, zVAD-fmk $(50 \mu \mathrm{M})$, ALLM $(40 \mu \mathrm{M})$, SP600125 $(20 \mu \mathrm{M})$, LY $294002(20 \mu \mathrm{M})$, H89 $(5 \mu \mathrm{M})$, Wortmannin $(1 \mu \mathrm{M}), \mathrm{U} 0126(20 \mu \mathrm{M})$, SB203580 $(20 \mu \mathrm{M})$ or PD98059 $(20 \mu \mathrm{M})$. Shrunken cells and cells with low $\Delta \Psi \mathrm{M}$ were counted by flow cytometry, as described in Figure 1. Lysates were separated by SDS-PAGE, and immunoblots were probed with anti-caspase-8, anti-bid and anti-caspase-3 Abs. The data represent the means \pm S.D. of three individual measurements. (b) Representative data from flow cytometric analysis of BL 41 cells after $13 \mathrm{~h}$ incubation without (-) or with $400 \mu \mathrm{M} \mathrm{Mn}{ }^{2+}(\mathrm{Mn})$ alone, or $400 \mu \mathrm{M} \mathrm{Mn}{ }^{2+}$ plus: $50 \mu \mathrm{M}$ AEVD (Mn + AEVD), $50 \mu \mathrm{M}$ zVAD (Mn + zVAD), $40 \mu \mathrm{M}$ ALLM (Mn + ALLM), $20 \mu \mathrm{M}$ SP600125 (Mn + SP600125), $20 \mu \mathrm{M} \mathrm{LY294002} \mathrm{(Mn} \mathrm{+} \mathrm{LY294002),} 5 \mu \mathrm{M} \mathrm{H89}$ (Mn + H89), or $1 \mu \mathrm{M}$ Wortmannin (Mn + Wortmannin), $20 \mu \mathrm{M}$ U0126 (Mn + U0126), $20 \mu \mathrm{M} \mathrm{SB203580} \mathrm{(Mn} \mathrm{+} \mathrm{SB203580).} \mathrm{The} \mathrm{caspase-8} \mathrm{and} \mathrm{caspase-3} \mathrm{activities} \mathrm{were}$ quantified by flow cytometry, as described in Figure 2. Data represent the mean \pm S.D. of three determinations

mediated by mitochondria even though more ROS and caspase-3 activation was observed. ${ }^{3}$ The potential roles of ROS and mitochondria, and the activation of several pathways have been established for different metals. ${ }^{34}$ In our model, using different inhibitors that regulated ROS production, we did not find any reduction in apoptotic level (data not shown), suggesting that ROS did not play any role in $\mathrm{Mn}^{2+}$ induced cell death in Burkitt lymphoma cells.

A role for p38-MAPK in caspase- 8 activation has been reported in various models. ${ }^{18,36,37}$ However, the mechanism of this activation is still poorly understood. P38-MAPKmediated cell death signal initiated by ROS is linked to activation of caspase- 8 in neuronal cell lines. ${ }^{18}$ P38-MAPK might regulate caspase-8 activation through direct molecular interactions leading to the regulation of caspase-8 activity. In neutrophils, p38-MAPK can directly phosphorylate and inhibit caspase- 8 activity and apoptosis. ${ }^{36}$ We did co-immunoprecipitations, but we could not find any association of caspase-8 with p38-MAPK in either inactive or active forms (data not shown) under our experimental conditions, suggesting that p38 does not react directly with caspase-8, but rather mobilizes other molecules to activate caspase-8. The p38mediated activation of caspase- 8 by $\mathrm{Mn}^{2+}$ is dependent on MSK1 activation in lymphoma $B$ cell lines. This raises the question of how MSK1 activates caspase-8. At least two mechanisms are possible: regulation of the transcription of regulator factors of caspase-8, or direct or indirect molecular interactions of caspase-8 with MSK1, leading to caspase-8 
a
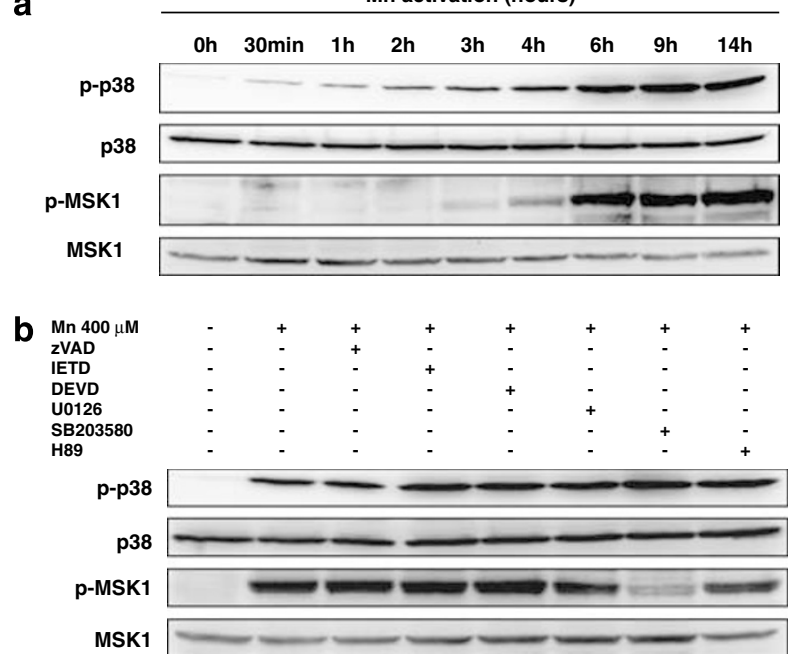

Figure $7 \mathrm{Mn}^{2+}$-mediated apoptosis and caspase-8 activation are p38 and MSK1 dependent. (a) BL41 cells were cultured for the times indicated with $400 \mu \mathrm{M}$ $\mathrm{Mn}^{2+}$, and the levels of phosphorylated p38 (p-p38), p38, phosphorylated MSK1 (p-MSK1) and MSK1 were determined by immunoblotting using specific antibodies. (b) Cells were cultured for $6 \mathrm{~h}$ without (-), or with $400 \mu \mathrm{M} \mathrm{Mn}^{2+}$ in combination with $50 \mu \mathrm{M}$ AEVD-fmk, $50 \mu \mathrm{M}$ zVAD-fmk (zVAD), $50 \mu \mathrm{M}$ specific caspase-3 inhibitor DEVD-fmk (DEVD), $5 \mu \mathrm{M} \mathrm{H89,} 20 \mu \mathrm{M}$ U0126 or $20 \mu \mathrm{M}$ SB203580. Cell extracts were separated by SDS-PAGE and immunoblots were probed with anti-p38, anti-pp38, anti-MSK1 and anti-p-MSK1 specific Abs

activation. The p38-MSK1 pathway is involved in transcriptional regulation, and we recently reported that association of the transcription factors SMAD3 and p300 triggered by TGF $\beta$ might represent an alternative pathway. ${ }^{26}$ P38-MAPK/MSK1dependent caspase- 8 activation triggered by $\mathrm{Mn}^{2+}$ may be related to regulation of transcription events. However, the addition of cycloheximide at non-toxic concentrations to prevent gene transcription (as measured by $\beta$-galactosidase activity in a gene reporter assay) did not prevent $\mathrm{Mn}^{2+}$. induced caspase-8 activation (data not shown). The rapid kinetics of caspase-8 activation (as short as $4 \mathrm{~h}$ in Ramos B cells) is compatible with another mechanism for MSK1 activity, independent of its involvement in transcriptional regulation. We never observed any phosphorylation of caspase-8 after $\mathrm{Mn}^{2+}$ stimulation, or association of MSK1 with caspase-8 by immunoprecipitation. A more likely hypothesis is that MSK1 might phosphorylate and activate other, as yet unidentified molecules that interact with and activate caspase- 8 . We are currently trying to characterize these potential modulators using mass-spectrometry analysis.

In conclusion, our results provide a novel and logical explanation for the molecular mechanism involved in the $\mathrm{Mn}^{2+}$-induced apoptosis of human lymphoma $\mathrm{B}$ cells. The activation of caspase- 8 induced by $\mathrm{Mn}^{2+}$ in these cells is associated with an original pathway, which is FADD-independent, and which is dependent on sequential p38-MAPK and MSK1 activation. Therefore, understanding the cascade of molecular signals in $\mathrm{Mn}^{2+}$-induced apoptosis of human lymphoma B cells may be helpful for B cell tumor therapy, with regard to the model of arsenic trioxide treatment of acute promyelocytic leukemia.

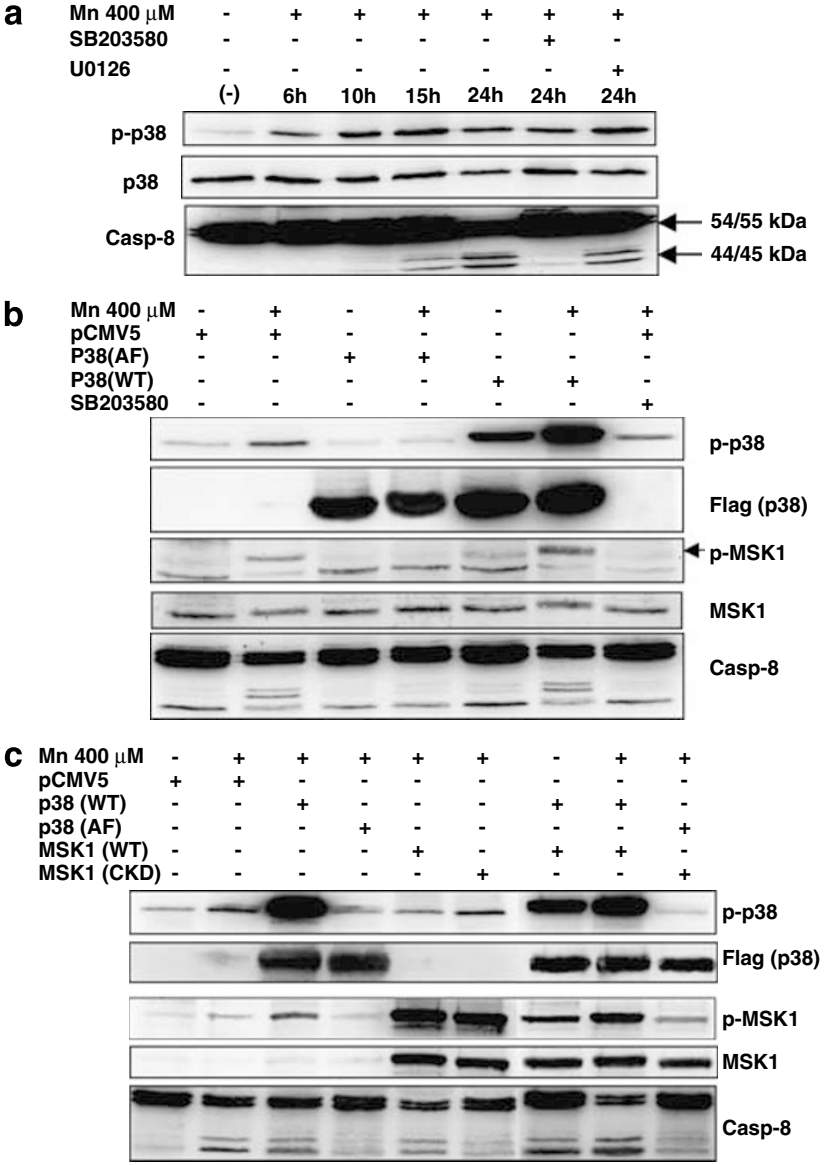

Figure 8 p38-MAPK and MSK1 control caspase-8 activation. (a) BJAB cells were incubated for different times at $37^{\circ} \mathrm{C}$ without (-), with $400 \mu \mathrm{M} \mathrm{Mn}^{2+}$ alone or in combination with $20 \mu \mathrm{M}$ SB203580, or $20 \mu \mathrm{M}$ U0126. Lysates were separated by SDS-PAGE, and immunoblots were probed with anti-caspase-8, and anti-p-p38 Abs. (b) The pCMV5 vector alone or vectors expressing either wild-type p38 $\alpha$ (p38 WT) or the dominant-negative form of $p 38$ (p38 AF) were co-transfected with a GFPexpressing plasmid into BJAB cells by electroporation. Cells were incubated at $37^{\circ} \mathrm{C}, 5 \% \mathrm{CO}_{2}$ for $24 \mathrm{~h}$. GFP-positive cells were isolated by flow cytometry, plated and immediately treated with $400 \mu \mathrm{M} \mathrm{Mn}^{2+}$ for $24 \mathrm{~h}$ without (-) or in combination with $20 \mu \mathrm{M}$ SB203580. Cell extracts were separated by SDS-PAGE and immunoblots were probed with anti-Flag (p38), anti-p-p38, anti-MSK1, anti-pMSK1 and anti-caspase- 8 Abs. (c) In addition to p38 $\alpha$ WT and AF vectors, wild-type MSK1 (MSK1 WT) or dominant-negative MSK1 (MSK1 CKD) were co-transfected with GFP into BJAB cells by elecroporation. Cells were plated and incubated for $24 \mathrm{~h}$. GFP-positive cells were purified by flow cytometry, plated and immediately treated with $400 \mu \mathrm{M} \mathrm{Mn}^{2+}$ for $24 \mathrm{~h}$. Immunoblots were probed with anti-Flag (p38), anti-p-p38, anti-MSK1, anti-p-MSK1 and anti-caspase-8 Abs

\section{Materials and Methods}

Reagents. $\mathrm{MnCl}_{2}$ was obtained from Sigma (St. Louis, MO, USA). Recombinant human TNF-related apoptosis-inducing ligand (TRAIL) was from R\&D Systems (Wiesbaden, Germany). zAEVDfmk, zIETD-fmk and zVAD-fmk were obtained from Bachem Biochimie SARL (Voisin le Bretonneux, France). Stock solutions of ZAEVDfmk $(20 \mathrm{mM})$, zIETD-fmk $(20 \mathrm{mM})$ and $\mathrm{zVAD}$-fmk $(100 \mathrm{mM})$ were prepared in dimethyl sulfoxide (DMSO) and stored at $-20^{\circ} \mathrm{C}$. Working dilutions were prepared immediately before use. The chemical DIOC6 and the MitoTracker Red CMXRos were purchased from Molecular Probes (Leiden, The Netherlands). SB203580, U0126, PD98059, LY294002, SP600125, H89, ALLM and Wortmannin were all obtained from Calbiochem (Strasbourg, France).

Cell lines. The Burkitt's lymphoma BL41 cell line was provided by Drs. A Calender and G Lenoir (Centre International de Recherche sur le Cancer, Lyon, 
France). The Ramos and BJAB Burkitt's cell lines were obtained from the American Type Culture Collection. For Ramos-bcl-2 isolation, the pSFFV-bcl2-neo vecto bearing the human bcl-2 cDNA was used to transfect Ramos cells by electroporation, and stable transfectants were isolated. The pCDNA3.0/FADD-DN vector (kindly provided by Dr. V Dixit, Genentech, San Francisco, CA, USA) carries a truncated FADD cDNA (aa 80/208) lacking the DED region. It was used to transfect BL41 cells by electroporation. Stable clonal transfectants were isolated. All cell lines were cultured in RPMI 1640 medium with Glutamax supplemented with $10 \%$ fetal calf serum (FCS), $100 \mathrm{U} / \mathrm{ml}$ penicillin, $100 \mu \mathrm{g} / \mathrm{ml}$ streptomycin, sodium pyruvate and nonessential amino acids (Life Technologies, Strasbourg, France).

Vectors. The FLAG-tagged versions of wild-type (WT) or dominant-negative forms (AF) of $p 38$ were kindly provided by Dr. J Han. AF is a p38 mutant that cannot be phosphorylated because the TGY dual phosphorylation sites were changed to AGF. The expression vectors PCMV5-FLAG MSK1 WT and MSK1 dead kinase (MSK1 C-terminal kinase dead (CKD) and MSK1 N-terminal kinase dead (NKD)) were gifts from Dr. DR Alessi. The pLL3.7-GFP vector expressing shRNAs agains caspase-8 (sh-Casp8), and the empty vector were both generous gifts from Dr. L Van Parijs. ${ }^{23}$ As control for shRNA, we used a scrambled sequence (5'-AATCGCATAGCGTATGCCGTT-3')

Cell transfection. The Burkitt lymphoma cells BJAB were maintained in RPMI medium with $10 \% \mathrm{FCS}$. Each vector pCMV5, p38 $\alpha$ (WT, AF), MSK1 WT and MSK1 (CKD, NKD) was cotransfected with GFP into $\left(2 \times 10^{7}\right)$ cells by electroporation at $0.24 \mathrm{kV}, 960 \mu \mathrm{F}$ using a Bio-Rad apparatus. Cells were plated and incubated at $37^{\circ} \mathrm{C}, 5 \% \mathrm{CO}_{2}$ for $24 \mathrm{~h}$. After expression of GFP protein, cells were selected by flow cytometry, plated and immediately treated with $400 \mu \mathrm{M} \mathrm{Mn}^{2+}$ for $24 \mathrm{~h}$. For pLL3.7 vectors expressing shRNAs Casp8-GFP, cells were transfected in the same conditions with these vectors, plated and incubated $48 \mathrm{~h}$ after expression of GFP protein; cells were selected by flow cytometry, replated and immediately incubated with $\mathrm{Mn}^{2+}$ for $24 \mathrm{~h}$ again.

Detection of apoptotic cells and analysis of $\Delta \Psi M$. Cells were washed in phosphate-buffered saline (PBS), pelleted and resuspended in PBS. Their dotblot light scatter profiles were analyzed by flow cytometry using a FACScan flow cytometer (BD Biosciences, Mountain View, CA, USA). Shrunken cells with relatively high side scatter and low forward scatter properties were considered to be apoptotic and were counted. The number of apoptotic cells was then expressed as a percentage of the total population. $\Delta \Psi \mathrm{M}$ was evaluated by staining cells $\left(10^{6}\right)$ with DIOC6 at a final concentration of $40 \mathrm{nM}$ (stock solution $40 \mu \mathrm{M}$ in ethanol) for $15 \mathrm{~min}$ at $37^{\circ} \mathrm{C}$ in the dark. The fluorescence emitted by cells was analyzed with a FACScan flow cytometer (BD Biosciences) using the fluorescence signal 1 channel.

Assay of caspase activity. Caspase activities were determined using the CaspaTag caspase-3 (Asp-Glu-Val-Asp (DEVD)), and caspase-8 (IETD) activity kits (Intergen, Purchase, NY, USA). These are carboxyfluorescein-labeled fluoromethyl ketone (FMK)-peptide inhibitors of caspases. These inhibitors are cell-permeable and noncytotoxic. Once inside the cell, the inhibitor binds covalently to the active caspase. Analysis of caspase activity was performed using flow cytometry. Briefly, cells were treated with $\mathrm{Mn}^{2+}(400 \mu \mathrm{M})$ with or without inhibitors and then incubated at $37^{\circ} \mathrm{C}$ with $5 \% \mathrm{CO}_{2}$ for $13 \mathrm{~h}$. Cells were then washed and resuspended in warmed, complete RPMI, supplemented with fluorochrome-peptide-fmk for $1 \mathrm{~h}$ at $37^{\circ} \mathrm{C}$ below $5 \% \mathrm{CO}_{2}$. Cells were washed and analyzed immediately by flow cytometry.

Western blotting. Cells were lysed in $20 \mathrm{mM}$ Tris ( $\mathrm{pH} 7.4$ ) and $0.5 \%$ SDS in the presence of $10 \mathrm{U}$ of Benzon nuclease (Merck Eurolab) for $5 \mathrm{~min}$ at room temperature and then boiled for $3 \mathrm{~min}$. Aliquots of the supernatants were used for protein determination (microBCA protein assay, Pierce). Cell lysates were subjected to SDS-polyacrylamide gel electrophoresis, and the proteins were then electrophoretically transferred onto nitrocellulose filters. The filters were probed with anti-caspase-8 (clone 5F7; Upstate Biotechnology, Lake Placid, NY, USA), anti-Bid (Cell Signaling Technology), anti-Mcl-1 (Santa Cruz, CA, USA), anticaspase-3 (polyclonal rabbit anti-caspase-3 antiserum, BD Pharmingen, San Diego, CA, USA), anti-cytochrome $c(7 \mathrm{H} 8.2 \mathrm{C12}, \mathrm{BD}$ Pharmingen) or anti-actin and antiFlag (Sigma, St. Louis, MO, USA). Antibody binding was detected by incubation with sheep anti-mouse or anti-rabbit IgG HRP-conjugated antibodies and chemiluminescence (West-pico or West femto, Pierce). Images were captured using a DDC camera (LAS-1000, Fuji). To analyze the phosphorylated proteins, cells were disrupted on ice for $30 \mathrm{~min}$ in lysis buffer $(20 \mathrm{mM}$ Tris, $\mathrm{pH} 7.4,150 \mathrm{mM}$
$\mathrm{NaCl}, 1 \mathrm{mM}$ ethylenediaminotetraacetic acid (EDTA), $1 \mathrm{mM}$ ethylene glycol-bis $(\beta$ aminoethyl ether)- $N, N, N, N$-tetraacetic acid (EGTA), $1 \%$ Triton, $2.5 \mathrm{mM}$ sodium pyrophosphate, $1 \mathrm{mM} \beta$-glycerol phosphate, $1 \mathrm{mM} \mathrm{Na}_{3} \mathrm{VO}_{4}, 1 \mathrm{mg} / \mathrm{ml}$ leupeptin and $1 \mathrm{mM}$ phenylmethylsulfonyl fluoride), centrifuged at $15000 \times \mathrm{g}$ for $15 \mathrm{~min}$ in a microcentrifuge, and levels of phosphorylated proteins of p-p38-MAPK, p-MSK1, total p38 and MSK1 were selectively measured by Western immunoblotting using specific antibodies: anti-p-p38 and anti-p-MSK1-Thr581 (Cell Signaling Technology, Beverly, MA, USA), anti-p38 and anti-MSK1 (Santa-Cruz, CA, USA).

Subcellular fractionation. Following induction of apoptosis, cytosolic and pellet (mitochondrial) fractions were generated using a digitonin-based subcellular fractionation technique. Briefly, $1 \times 10^{7}$ cells were harvested by centrifugation at $800 \times g$, washed in PBS, pH 7.2 and re-pelleted. Cells were digitonin-permeabilized for $5 \mathrm{~min}$ on ice at a density of $3 \times 10^{7} / \mathrm{ml}$ in cytosolic extraction buffer $(250 \mathrm{mM}$ sucrose, $70 \mathrm{mM} \mathrm{KCl}, 137 \mathrm{mM} \mathrm{NaCl}, 4.3 \mathrm{mM} \mathrm{Na}_{2} \mathrm{HPO}_{4}, 1.4 \mathrm{mM} \mathrm{KH}_{2} \mathrm{PO}_{4}, \mathrm{pH} 7.2$, $100 \mathrm{mM}$ phenylmethylsulfonyl fluoride (PMSF), $10 \mathrm{mg} / \mathrm{ml}$ leupeptin, $2 \mathrm{mg} / \mathrm{ml}$ aprotinin, containing $200 \mathrm{mg} / \mathrm{ml}$ digitonin). Plasma membrane permeabilization of cells was confirmed by staining in a $0.2 \%$ trypan blue solution. Cells were then centrifuged at $1000 \times g$ for $15 \mathrm{~min}$ at $4^{\circ} \mathrm{C}$. The supernatants (cytosolic fractions) were saved and the pellets solubilized in the same volume of mitochondrial lysis buffer ( $50 \mathrm{mM}$ Tris, pH 7.4, $150 \mathrm{mM} \mathrm{NaCl}, 2 \mathrm{mM}$ EDTA, $2 \mathrm{mM} \mathrm{EGTA}, 0.2 \%$ Triton X$100,0.3 \%$ NP-40, $100 \mathrm{mM} \mathrm{PMSF}, 10 \mathrm{mg} / \mathrm{ml}$ leupeptin, $2 \mathrm{mg} / \mathrm{ml}$ aprotinin), followed by pelleting at $10000 \times g$ for $10 \mathrm{~min}$ at $4^{\circ} \mathrm{C}$ for the detection of Cyt $C$.

Acknowledgements. This work was supported by Institut National de la Santé et de la Recherche Médicale and grants from the Fondation de France and Association pour la Recherche sur le Cancer. B El Mchichi and A Hadji hold fellowships from Société Française d'Hématologie and Ministère de la Recherche, respectively.

1. Olanow CW. Manganese-induced parkinsonism and Parkinson's disease. Ann NY Acad Sci 2004; 1012: 209-223.

2. Desole MS, Sciola L, Delogu MR, Sircana S, Migheli R, Miele E. Role of oxidative stress in the manganese and 1-methyl-4-(2'-ethylphenyl)-1,2,3,6-tetrahydropyridine-induced apoptosis in PC12 cells. Neurochem Int 1997; 31: 169-176.

3. Oubrahim H, Stadtman ER, Chock PB. Mitochondria play no roles in $\mathrm{Mn}(\mathrm{II})$-induced apoptosis in HeLa cells. Proc Natl Acad Sci USA 2001; 98: 9505-9510.

4. Roth JA, Feng L, Walowitz J, Browne RW. Manganese-induced rat pheochromocytoma (PC12) cell death is independent of caspase activation. J Neurosci Res 2000; 61: 162-171.

5. Schrantz N, Blanchard DA, Mitenne F, Auffredou MT, Vazquez A, Leca G. Manganese induces apoptosis of human $B$ cells: caspase-dependent cell death blocked by bcl-2. Cell Death Differ 1999; 6: 445-453.

6. Roth JA, Garrick MD. Iron interactions and other biological reactions mediating the physiological and toxic actions of manganese. Biochem Pharmacol 2003; 66: 1-13.

7. Roth JA, Horbinski C, Higgins D, Lein $P$, Garrick MD. Mechanisms of manganese-induced rat pheochromocytoma (PC12) cell death and cell differentiation. Neurotoxicology 2002; 23: $147-157$.

8. Kitazawa M, Wagner JR, Kirby ML, Anantharam V, Kanthasamy AG. Oxidative stress and mitochondrial-mediated apoptosis in dopaminergic cells exposed to methylcyclopentadienyl manganese tricarbonyl. J Pharmacol Exp Ther 2002; 302: 26-35.

9. Anantharam V, Kitazawa M, Wagner J, Kaul S, Kanthasamy AG. Caspase-3-dependent proteolytic cleavage of protein kinase Cdelta is essential for oxidative stress-mediated dopaminergic cell death after exposure to methylcyclopentadienyl manganese tricarbonyl. J Neurosci 2002; 22: 1738-1751.

10. Latchoumycandane C, Anantharam V, Kitazawa M, Yang Y, Kanthasamy A, Kanthasamy AG. Protein kinase Cdelta is a key downstream mediator of manganese-induced apoptosis in dopaminergic neuronal cells. J Pharmacol Exp Ther 2005; 313: 46-55.

11. Oubrahim H, Chock PB, Stadtman ER. Manganese(II) induces apoptotic cell death in NIH3T3 cells via a caspase-12-dependent pathway. J Biol Chem 2002; 277: 20135-20138.

12. Dong C, Davis RJ, Flavell RA. MAP kinases in the immune response. Annu Rev Immunol 2002; 20: 55-72.

13. Ono K, Han J. The p38 signal transduction pathway: activation and function. Cell Signal 2000; 12: 1-13.

14. Platanias LC. Map kinase signaling pathways and hematologic malignancies. Blood 2003; 101: $4667-4679$

15. Tallman MS. Arsenic trioxide: its role in acute promyelocytic leukemia and potential in other hematologic malignancies. Blood Rev 2001; 15: 133-142.

16. Giafis N, Katsoulidis E, Sassano A, Tallman MS, Higgins LS, Nebreda AR et al. Role of the p38 mitogen-activated protein kinase pathway in the generation of arsenic trioxidedependent cellular responses. Cancer Res 2006; 66: 6763-6771. 
17. Kannan-Thulasiraman P, Katsoulidis E, Tallman MS, Arthur JS, Platanias LC. Activation of the mitogen- and stress-activated kinase 1 by arsenic trioxide. J Biol Chem 2006; 281 : 22446-22452.

18. Choi WS, Eom DS, Han BS, Kim WK, Han BH, Choi EJ et al. Phosphorylation of p38 MAPK induced by oxidative stress is linked to activation of both caspase-8- and -9-mediated apoptotic pathways in dopaminergic neurons. J Biol Chem 2004; 279: 20451-20460.

19. Schrantz N, Bourgeade MF, Mouhamad S, Leca G, Sharma S, Vazquez A. p38-mediated regulation of an Fas-associated death domain protein-independent pathway leading to caspase-8 activation during TGFbeta-induced apoptosis in human Burkitt lymphoma B cells BL41. Mol Biol Cell 2001; 12: 3139-3151.

20. Schrantz N, Auffredou MT, Bourgeade MF, Besnault L, Leca G, Vazquez A. Zinc-mediated regulation of caspases activity: dose-dependent inhibition or activation of caspase-3 in the human Burkitt lymphoma B cells (Ramos). Cell Death Differ 2001; 8: 152-161.

21. Green DR, Kroemer G. The pathophysiology of mitochondrial cell death. Science 2004 305: $626-629$.

22. Suzuki T, Tsukamoto I. Manganese-induced apoptosis in hepatocytes after partia hepatectomy. Eur J Pharmacol 2005; 525: 48-53.

23. Su H, Bidere N, Zheng L, Cubre A, Sakai K, Dale J et al. Requirement for caspase-8 in NFkappa B activation by antigen receptor. Science 2005; 307: 1465-1468.

24. Besnault L, Schrantz N, Auffredou MT, Leca G, Bourgeade MF, Vazquez A. B cell receptor cross-linking triggers a caspase-8-dependent apoptotic pathway that is independent of the death effector domain of Fas-associated death domain protein. $J$ Immunol 2001; 167 : 733-740.

25. Davies SP, Reddy H, Caivano M, Cohen P. Specificity and mechanism of action of some commonly used protein kinase inhibitors. Biochem J 2000; 351: 95-105.

26. Abecassis L, Rogier E, Vazquez A, Atfi A, Bourgeade MF. Evidence for a role of MSK1 in transforming growth factor-beta-mediated responses through p38alpha and Smad signaling pathways. J Biol Chem 2004; 279: 30474-30479.
27. Budihardjo I, Oliver $\mathrm{H}$, Lutter M, Luo X, Wang X. Biochemical pathways of caspase activation during apoptosis. Annu Rev Cell Dev Biol 1999; 15: 269-290.

28. Siegel RM. Caspases at the crossroads of immune-cell life and death. Nat Rev Immunol 2006; 6: 308-317.

29. Tibbetts MD, Zheng L, Lenardo MJ. The death effector domain protein family: regulators of cellular homeostasis. Nat Immunol 2003; 4: 404-409.

30. Wesselborg S, Engels IH, Rossmann E, Los M, Schulze-Osthoff K. Anticancer drugs induce caspase-8/FLICE activation and apoptosis in the absence of CD95 receptor/ligand interaction. Blood 1999; 93: 3053-3063.

31. Rebe C, Cathelin S, Launay S, Filomenko R, Prevotat L, L'Ollivier C et al. Caspase-8 prevents sustained activation of NF-kappaB in monocytes undergoing macrophagic differentiation. Blood 2007; 109: 1442-1450.

32. Bae JH, Jang BC, Suh SI, Ha E, Baik HH, Kim SS et al. Manganese induces inducible nitric oxide synthase (iNOS) expression via activation of both MAP kinase and PI3K/Akt pathways in BV2 microglial cells. Neurosci Lett 2006; 398: 151-154.

33. Sugden $\mathrm{PH}$, Clerk A. Oxidative stress and growth-regulating intracellular signaling pathways in cardiac myocytes. Antioxid Redox Signal 2006; 8: 2111-2124.

34. Pulido MD, Parrish AR. Metal-induced apoptosis: mechanisms. Mutat Res 2003; 533 227-241.

35. Fiers W, Beyaert R, Declercq W, Vandenabeele P. More than one way to die: apoptosis, necrosis and reactive oxygen damage. Oncogene 1999; 18: 7719-7730.

36. Alvarado-Kristensson M, Melander F, Leandersson K, Ronnstrand L, Wernstedt C, Andersson T. p38-MAPK signals survival by phosphorylation of caspase-8 and caspase- 3 in human neutrophils. J Exp Med 2004; 199: 449-458.

37. Park MT, Choi JA, Kim MJ, Um HD, Bae S, Kang CM et al. Suppression of extracellular signal-related kinase and activation of p38 MAPK are two critical events leading to caspase-8- and mitochondria-mediated cell death in phytosphingosine-treated human cancer cells. J Biol Chem 2003; 278: 50624-50634. 